\title{
Kepuasan Dan Loyalitas Petani Jagung Menggunakan Benih Bersubsidi Di Desa Laubaleng Kecamatan Laubaleng Kabupaten Karo
}

\author{
Nana Trisna Mei Br Kabeakan ${ }^{*}$ \\ Juita Rahmadani Manik ${ }^{2}$ \\ 1,2Fakultas Pertanian Universitas Muhammadiyah Sumatera Utara \\ *email: nanatrisna@umsu.ac.id \\ Diterima: September 2020, Disetujui: Oktober 2020, Dipublish: Oktober 2020
}

\begin{abstract}
Abstrak
Salah satu faktor terpenting yang dapat menentukan tinggi atau rendahnya hasil produksi tanaman adalah benih yang bermutu baik dan berasal dari varietas unggul, namun harga benih unggul yang tinggi membuat biaya produksi petani meningkat sehingga pemerintah berupaya untuk meringankan beban petani dengan memberikan benih bersubsidi. Di sisi lain alasan petani menggunakan benih bersubsidi menjadi pertanyaan tersendiri, apakah petani jagung merasa puas terhadap hasil produksi jagung atau petani menggunakan benih jagung bersubsidi hanya karena diperoleh dari bantuan pemerintah. Penelitian ini bertujuan untuk mengetahui dan menganalisis pengaruh produk dan distribusi terhadap kepuasan petani jagung menggunakan benih bersubsidi serta untuk mengetahui dan menganalisis pengaruh produk, distribusi dan kepuasan petani jagung terhadap loyalitas petani jagung menggunakan benih bersubsidi. Penelitian ini dilaksanakan di Desa Laubaleng Kecamatan Laubaleng Kabupaten Karo dengan Jumlah sampel sebanyak 30 orang. Metode analisis data yang digunakan dalam penelitian ini adalah analisis jalur (path analysis). Hasil penelitian menunjukkan bahwa produk dan distribusi secara serempak dan parsial berpengaruh signifikan terhadap kepuasan petani jagung menggunakan benih bersubsidi serta produk, distribusi dan kepuasan secara serempak dan parsial berpengaruh positif dan signifikan terhadap loyalitas petani jagung menggunakan benih bersubsidi. Berdasarkan hasil penelitian maka dapat diketahui bahwa petani jagung merasa puas terhadap benih bersubsidi dengan produk dan distribusi sebagai variabel yang mempengaruhi kemudian juga dapat diketahui bahwa petani jagung loyal terhadap benih bersubsidi dengan produk, distribusi dan kepuasan sebagai variabel yang mempengaruhi.
\end{abstract}

Kata Kunci: Benih, Distribusi, Kepuasan, Loyalitas, Petani

\begin{abstract}
One of the most important factors that can determine the crop productions are quality seeds and derived from superior varieties. However, high prices of superior seeds make farmers' production costs increase so the government tries to ease the burden on farmers by providing subsidized seeds. On the other hand, the reason of farmers using subsidized seeds is a separate question, whether corn farmers are satisfied with the results of corn production or farmers use subsidized corn seeds only because it is obtained from government assistance. This study aims to determine and analyze the effect of products and distribution on the satisfaction of corn farmers using subsidized seeds and to determine and analyze the effect of product, distribution and satisfaction of corn farmers on the loyalty of corn farmers. This study conducted in Laubaleng Village Laubaleng Sub District Karo Regency with sample were 30 peoples. The data analysis method used in this study is path analysis. The results showed that the product and distribution
\end{abstract}


simultaneously and partially had a significant effect on the satisfaction of corn farmers and the product, distribution and satisfaction simultaneously and partially had a positive and significant effect on the loyalty of corn farmers using subsidized seeds. Based on the research results it can find that corn farmers are satisfied with the subsidized seeds with a product and distribution as affecting variables. It can also found that corn farmers are loyal with subsidized seeds with a product, distribution, and satisfaction as affecting variables.

Keywords: Seed, Distribution, Satisfaction, Loyalty, Farmer

\section{PENDAHULUAN}

Menurut informasi yang diperolah dari Badan Penelitian dan Pengembangan Pertanian (2012) jagung merupakan salah satu jenis tanaman serelia yang berfungsi sebagai bahan pangan utama sumber karbohidrat, selain sebagai sumber karbohidrat jagung juga merupakan sumber protein penting. Manfaat lain yang dimiliki jagung adalah sebagai sumber pakan ternak, biji jagung sering diolah menjadi minyak dan tepung serta dapat dimanfaatkan sebagai bahan baku untuk industri.

Indonesia merupakan salah satu negara penghasil jagung di dunia dan salah satu provinsi penghasil jagung di Indonesia adalah Provinsi Sumatera Utara, berdasarkan informasi yang diperoleh dari Badan Pusat Statistik (BPS, 2020) dimana pada tahun 2019 produksi jagung Sumatera Utara sebanyak 1.960.424 ton dan Kabupaten Karo merupakan kabupaten penghasil jagung terbesar di Sumatera Utara, produksi jagung pada tahun 2019 sebanyak 767.304,59 ton dengan luas panen 108.898,1 hektar.

Benih merupakan salah satu sarana produksi penting yang mempengaruhi produksi. Peranan benih sangat penting bagi budidaya tanaman. Warisno (2009) menyatakan bahwa benih yang bermutu baik dan berasal dari varietas unggul adalah faktor terpenting yang dapat menentukan tinggi atau rendahnya hasil tanaman. Benih yang bermutu mampu meningkatkan produksi pertanian dan mengurangi serangan hama dan penyakit di lapangan. Salah satu cara untuk mengetahui benih bermutu atau tidak adalah dengan adanya sertifikasi benih. Rukmana (2011) menyatakan bahwa menggunakan benih unggul bersertifikasi memiliki manfaat dalam menghemat jumlah pemakaian benih persatuan luas areal, keseragaman pertumbuhan tanaman, mengurangi susut hasil, menjamin peningkatan hasil yang optimal.

Hasil produksi yang optimal dapat mendukung usaha pemerintah dalam upaya untuk mencapai swasembada pangan. Untuk mewujudkan produksi yang optimal tersebut maka salah satu upaya yang dilakukan oleh pemerintah adalah dengan memberikan benih unggul bersubsidi kepada petani. Berdasarkan peraturan menteri pertanian nomor 67 tahun 2013 bahwa benih bersubsidi yang dijual dan disalurkan dalam budidaya tanaman pangan harus memenuhi standar mutu benih bina. Benih bina adalah benih dari varietas unggul yang telah dilepas produksi dan peredarannya diawasi, kemudian selanjutnya benih bersubsidi adalah benih padi (inbrida dan hibrida), jagung (komposit dan 
hibrida) dan kedelai bersertifikat yang mendapatkan subsidi bersumber dari dana APBN dalam proses penyediaan, penjualan dan penyalurannya oleh produsen benih pelaksana PSO subsidi benih. Desa Laubaleng, Kecamatan Laubaleng, Kabupaten Karo merupakan penghasil jagung terbesar kelima dari 15 desa di Kecamatan Laubaleng dengan produksi 10.316 ton pada tahun 2018 (BPS, 2019) dan petani di Desa Laubaleng termasuk yang menjadi penerima benih bersubsidi. Saat ini benih jagung yang disubsidi oleh pemerintah adalah adalah benih jagung hibrida varietas BISI 18. Keunggulan jagung super hibrida BISI 18 antara lain tongkolnya sangat seragam dengan letak tongkol yang relatif sama antara masing-masing tanaman, tingkat penutupan pucuk tongkolnya (tip filling) bisa mencapai 97\% hampir semua tongkol jagung BISI-18 memiliki biji yang muput atau penuh hingga ujung tongkol, produksi jagung bisa mencapai 12 ton/Ha pipil kering. Dengan berbagai keunggulan benih jagung yang disubsidi diharapkan sesuai dengan kebutuhan petani dan juga dengan ketersediaan benih bersubsidi membantu petani untuk melancarkan kegiatan usahataninya.

Dalam penggunaan produk seseorang akan merasakan kepuasan atau ketidakpuasan terhadap suatu produk, artinya apakah produk tersebut sesuai atau tidak dengan yang diharapkan. Sangadji dan Sopiah (2013) menyatakan bahwa kepuasan adalah perasaan senang atau kecewa seseorang membandingkan antara kesannya terhadap kinerja produk yang rill dengan kinerja yang diharapkan. Mustikarini (2014) menyatakan bahwa kepuasan juga dapat diartikan sebagai evaluasi pascakonsumsi bahwa suatu alternatif yang dipilih setidaknya bekerja sebaik yang diharapkan.

Distribusi produk merupakan hal yang sangat penting berkaitan dengan petani memperoleh benih subsidi, karena penyaluran benih yang tepat dapat membuat petani menggunakan benih sesuai dengan kebutuhannya. Mayrowani (2008) dalam penelitiannya berjudul "Evaluasi Kebijakan Subsidi Benih Jagung Kasus Kabupaten Jeneponto, Sulawesi Selatan" bahwa dampak subsidi benih terhadap produksi, produktivitas, dan pendapatan petani sangat bervariasi yang masing-masing ditentukan oleh penerimaan subsidi benih yang tepat. Penggunaan benih jagung bersubsidi oleh petani yang tidak sesuai dengan harapan petani maka dapat menyebabkan ketidakpuasan petani, sebaliknya kemampuan benih jagung bersubsidi untuk memenuhi harapan sehingga petani merasakan manfaat dari benih tersebut seperti kualitas produk benih yang baik, kemudahan dalam mendapatkannya dan meningkatkan produksi serta produktivitas jagung yang diharapkan mampu meningkatkan pendapatan petani akan dapat memberikan kepuasan kepada petani yang akan berakibat kepada loyalitas petani dalam penggunaan benih jagung bersubsidi.

Program benih jagung bersubsidi merupakan salah satu upaya pemerintah dalam upaya mencapai swasembada pangan, benih jagung bersubsidi dalam penggunaanya 
diharapkan mampu memberikan kepuasan dan loyalitas kepada petani. Oleh karena itu perumusan masalah dalam penelitian ini adalah bagaimana pengaruh produk dan distribusi terhadap kepuasan petani jagung menggunakan benih bersubsidi serta bagaimana pengaruh produk, distribusi dan kepuasan petani jagung terhadap loyalitas petani jagung menggunakan benih bersubsidi.

\section{METODE PENELITIAN}

Penelitian ini dilakukan di Desa Laubaleng Kecamatan Laubaleng Kabupaten Karo. Lokasi penelitian ditentukan secara purposive (sengaja) dengan pertimbangan bahwa Desa Laubaleng merupakan salah satu desa penghasil jagung terbesar di Kecamatan Laubaleng dan termasuk desa penerima bantuan benih jagung bersubsidi. Penelitian dilaksanakan pada bulan Mei sampai Juni 2020. Populasi dalam penelitian ini adalah seluruh petani jagung yang masih tergabung dalam kelompok tani di Desa Laubaleng pada bulan Mei sampai Juni 2020, jumlah kelompok tani di Desa Laubaleng sebanyak 40 kelompok dengan jumlah anggota berkisar 20 hingga 25 orang setiap kelompoknya. Jumlah sampel dalam penelitian ini sebesar 30 orang petani jagung, Roscoe dalam buku Research Methods For Business memberikan saran bahwa ukuran sampel minimal adalah 30 orang (Sugiyono, 2012). Teknik pengambilan sampel dilakukan dengan proportional random sampling, teknik ini digunakan bila populasi mempunyai kategori dan proporsional.

Metode analisis data dilakukan dengan menggunakan statistik deskriptif dan analisis jalur (path analysis). statistik deskriptif adalah statistik yang berfungsi untuk mendeskripsikan atau memberi gambaran terhadap objek yang diteliti melalui data sampel atau populasi sebagaimana adanya, tanpa membuat kesimpulan-kesimpulan yang berlaku secara umum. Sinulingga (2013) menyatakan bahwa analisis jalur ialah teknik analisis hubungan sebab akibat dimana variabel-variabel bebas mempengaruhi variabel terikat baik secara langsung maupun tidak langsung.

Persamaan model matematika dari model jalur (path analysis) tersebut adalah sebagai berikut:

a. Persamaan Struktural 1

$\mathrm{Y}_{1}=p_{1} \mathrm{X}_{1}+p_{2} \mathrm{X}_{2}+\mathrm{e}_{1}$

b. Persamaan Struktural 2

$$
\mathrm{Y}_{2}=p_{3} \mathrm{X}_{1}+p_{4} \mathrm{X}_{2}+p_{5} \mathrm{Y}_{1}+\mathrm{e}_{2}
$$

Keterangan:

$\mathrm{Y}_{1}=$ Kepuasan Petani Jagung

$\mathrm{Y}_{2}=$ Loyalitas Petani Jagung

$p_{1}, \ldots ., p_{5}=$ Koefisien Regresi

$\mathrm{X}_{1} \quad=$ Produk

$\mathrm{X}_{2} \quad=$ Distribusi

$\mathrm{e}_{1}, \mathrm{e}_{2}=$ error term

\section{HASIL DAN PEMBAHASAN}

\section{Karakteristik Responden}

Karakteristik responden dalam penelitian ini meliputi jenis kelamin, usia, pendidikan, jumlah tanggungan dan lama bertani atau pengalaman bertani. Karakteristik petani yang merupakan responden dalam penelitian ini berdasarkan jenis kelamin dapat dilihat pada Tabel 1 berikut: 
Tabel 1 Karakteristik Responden Berdasarkan Jenis Kelamin

\begin{tabular}{cccc}
\hline No & Jenis Kelamin & Jumlah (Orang) & $\mathbf{( \% )}$ \\
\hline 1 & Laki-Laki & 21 & 70 \\
2 & Perempuan & 9 & 30 \\
\hline & Jumlah & 30 & 100 \\
\hline
\end{tabular}

Sumber: Hasil Penelitian 2020 (Data Diolah)

Berdasarkan Tabel 1 dapat diketahui bahwa responden dalam penelitian ini didominasi jenis kelamin laki-laki dengan rincian laki-laki sebanyak 21 orang atau $70 \%$ dan perempuan sebanyak 9 orang atau $30 \%$. Hal ini disebabkan bahwa kegiatan bertani merupakan mata pencaharian masyarakat yang dilakukan oleh laki-laki sebagai kepala keluarga.

Karakteristik petani yang merupakan responden dalam penelitian ini berdasarkan usia dapat dilihat pada Tabel 2 berikut:

Tabel 2 Karakteristik Responden Berdasarkan Usia

\begin{tabular}{cccc}
\hline No & Usia (Tahun) & Jumlah (Orang) & (\%) \\
\hline 1 & $20-35$ & 4 & 13,3 \\
2 & $36-55$ & 18 & 60 \\
3 & $\geq 56$ & 8 & 26,7 \\
\hline & Jumlah & 30 & 100 \\
\hline
\end{tabular}

Sumber: Hasil Penelitian 2020 (Data Diolah)

Berdasarkan Tabel 2 dapat diketahui bahwa tingkatan usia petani yang menjadi responden dalam penelitian ini memiliki variasi yang berbeda. Responden yang berada pada rentang usia 20-35 tahun sebanyak 4 orang atau $13,3 \%$, responden berusia 36-55 tahun sebanyak 18 orang atau $60 \%$ dan responden berusia $\geq 56$ tahun sebanyak 8 orang atau $26,7 \%$. Hal ini menunjukkan bahwa responden dalam penelitian ini merupakan petani dengan usia produktif yang artinya petani-petani tersebut masih memiliki kemampuan untuk mengelola usahatani mereka.

Karakteristik petani yang merupakan responden dalam penelitian ini berdasarkan pendidikan dapat dilihat pada Tabel 3 berikut:

Tabel 3 Karakteristik Responden Berdasarkan Pendidikan

\begin{tabular}{cccc}
\hline No & Pendidikan & Jumlah (Orang) & $\mathbf{( \% )}$ \\
\hline 1 & SD & 2 & 6,67 \\
2 & SMP & 8 & 26,67 \\
3 & SMA dan Sederajat & 18 & 60 \\
4 & Perguruan Tinggi & 2 & 6,66 \\
\hline & Jumlah & 30 & 100 \\
\hline
\end{tabular}

Sumber: Hasil Penelitian 2020 (Data Diolah)

Berdasarkan Tabel 3 dapat diketahui bahwa responden dengan pendidikan terakhir dari perguruan tinggi 2 orang atau $6,66 \%$ sedangkan 28 lainnya 
memiliki tingkat pendidikan terakhir SD, SMP, SMA sederajat dan dalam penelitian ini responden didominasi dengan pendidikan terakhir SMA sederajat sebanyak 18 orang atau $60 \%$. Habib (2013) menyatakan bahwa pendidikan berkaitan dengan wawasan dan daya serap petani dalam menelaah setiap informasi dan teknologi yang berguna bagi kemajuan pertanian.

Karakteristik petani yang merupakan responden dalam penelitian ini berdasarkan jumlah tanggungan dapat dilihat pada Tabel 4 berikut:

Tabel 4 Karakteristik Responden Berdasarkan Jumlah Tanggungan

\begin{tabular}{cccc}
\hline No & Jumlah Tanggungan (Orang) & Jumlah (Orang) & $\mathbf{( \% )}$ \\
\hline 1 & $0-2$ & 12 & 40 \\
2 & $3-4$ & 13 & 43,33 \\
3 & $\geq 5$ & 5 & 16,67 \\
\hline & Jumlah & 30 & 100 \\
\hline
\end{tabular}

Sumber: Hasil Penelitian 2020 (Data Diolah)

Berdasarkan Tabel 4 dapat diketahui bahwa responden dengan jumlah tanggungan $0-2$ orang sebanyak 12 orang atau $40 \%$, jumlah tanggungan 3-4 orang sebanyak 13 orang atau 43,33\%, jumlah tanggungan $\geq 5$ orang sebanyak 5 orang atau $16,67 \%$. Jumlah tanggungan berkaitan dengan pengeluaran yang harus dikeluarkan oleh responden dalam kegiatan sehari-harinya dan dengan adanya benih bersubsidi maka pengeluaran petani dapat dialihkan ke hal-hal lain yang diperlukan.

Karakteristik petani yang merupakan responden dalam penelitian ini berdasarkan lama bertani dapat dilihat pada Tabel 5 berikut:

Tabel 5 Karakteristik Responden Berdasarkan Lama Bertani

\begin{tabular}{cccc}
\hline No & Lama Bertani (Tahun) & Jumlah (Orang) & (\%) \\
\hline 1 & $0-10$ & 16 & 53,33 \\
2 & $11-20$ & 12 & 40 \\
3 & $21-30$ & 2 & 6,67 \\
\hline & Jumlah & 30 & 100
\end{tabular}

Sumber: Hasil Penelitian 2020 (Data Diolah)

Berdasarkan Tabel 5 dapat diketahui sudah berapa lama petani yang menjadi responden melakukan kegiatan usahatani jagung. Responden dengan lama bertani 0-10 tahun sebanyak 16 orang atau $53,33 \%$, lama bertani $11-20$ tahun sebanyak 12 orang atau $40 \%$ dan lama bertani 21-30 tahun sebanyak 2 orang atau $6,67 \%$ artinya petani yang menjadi responden dalam penelitian ini bisa dikatakan sudah memiliki pengalaman yang sangat cukup dalam melakukan usahatani jagung dan juga sebagai penerima benih bersubsidi, ketika petani masih bergabung dengan kelompok tani maka petani akan menerima benih 
bersubsidi dari pemerintah karena bergabung dengan kelompok tani merupakan syarat untuk memperoleh benih bersubsidi.

\section{Pengujian Hipotesis Persamaan Struktural 1}

Berdasarkan Tabel 6 dapat diketahui bahwa koefisien determinasi (R Square) adalah 0,250 atau $25 \%$ artinya pengaruh produk dan distribusi terhadap kepuasan petani jagung menggunakan benih bersubsidi sebesar 25\% sedangkan sisanya $75 \%$ dipengaruhi oleh faktor lain seperti sikap petani dan lainnya yang tidak diteliti pada penelitian ini.

Tabel 6 Model Summaryb

\begin{tabular}{lllll}
\hline Model & R & R Square & Adjusted R Square & $\begin{array}{l}\text { Std. Error of the } \\
\text { Estimate }\end{array}$ \\
\hline $\mathbf{1}$ &, $500^{\mathrm{a}}$ &, 250 &, 194 &, 55205 \\
\hline
\end{tabular}

Sumber: Hasil Penelitian 2020 (Data Diolah)

\section{Pengujian Secara Serempak (Uji F)}

Hasil analisis data yang dapat dilihat pada Tabel 7 menunjukkan bahwa F-hitung adalah 4,492 dengan tingkat signifikansi $95 \%(\alpha=0,05)$. Oleh karena F-hitung> Ftabel $\quad(4,492>3,354)$ dan nilai signifikansinya $\quad(0,021)<0,05, \quad$ maka produk dan distribusi secara serempak berpengaruh positif dan signifikan terhadap kepuasan petani jagung menggunakan benih bersubsidi

Tabel 7. ANOVAa

\begin{tabular}{lrrrrr}
\hline Model & Sum of Squares & df & Mean Square & F & Sig. \\
\hline 1 Regression & 2,738 & 2 & 1,369 & 4,492 &, $021^{\mathrm{b}}$ \\
Residual & 8,229 & 27 &, 305 & & \\
Total & 10,967 & 29 & & & \\
\hline Sumber: Hasil Penelitian 2020 (Data Diolah) & & &
\end{tabular}

\section{Hasil Uji Koefisien Jalur Struktural 1}

Hasil output uji analisis jalur persamaan struktural 1 secara parsial yaitu pengaruh produk dan distribusi terhadap kepuasan dapat dilihat pada Tabel 8 berikut:

Tabel 8. Cofficients ${ }^{\mathrm{a}}$

\begin{tabular}{lrrrrr}
\hline Model & \multicolumn{2}{c}{$\begin{array}{l}\text { Unstandardized } \\
\text { Coefficients }\end{array}$} & $\begin{array}{c}\text { Standardized } \\
\text { Coefficients }\end{array}$ & t & \multicolumn{1}{c}{ Sig. } \\
\cline { 2 - 4 } & \multicolumn{1}{c}{ B } & \multicolumn{1}{c}{ Std. Error } & \multicolumn{1}{c}{ Beta } & & \\
1 (Constant) & 7,570 &, 952 & & 7,954 &, 000 \\
Produk &,- 143 &, 065 &,- 420 & $-2,194$ &, 037 \\
Distribusi &, 357 &, 125 &, 548 & 2,858 &, 008 \\
\hline
\end{tabular}

Sumber: Hasil Penelitian 2020 (Data Diolah) 
Berdasarkan Tabel 8 dapat diketahui bahwa:

1. Produk berpengaruh signifikan terhadap kepuasan petani jagung menggunakan benih bersubsidi, hal ini terlihat dari nilai signifikan $0,037<0,05$. Produk yang dimaksud dalam penelitian ini adalah benih jagung yang disubsidi oleh pemerintah kepada petani jagung yang bergabung dalam kelompok tani. Tjiptono (2008) mengemukakan kepuasan pelanggan adalah perasaan yang timbul setelah mengevaluasi pengalaman pemakaian produk. Harapan merupakan perkiraan atau keyakinan seseorang tentang apa yang akan diterimanya. Salah satu faktor yang menentukan harapan antara lain adalah kebutuhan. Benih merupakan salah satu yang paling dibutuhkan oleh petani dalam kegiatan usahataninya. Dengan adanya benih bersubsidi juga dapat mengurangi biaya produksi yang harus dikeluarkan petani dalam usahatani mereka. Produk yang berkualitas dapat memberikan dampak positif kepada kepuasan petani. Hal ini juga sesuai dengan penelitian Rahmawati et.al (2018) bahwa kualitas produk berpengaruh signifikan terhadap kepuasan pelanggan.

2. Distribusi berpengaruh positif dan signifikan terhadap kepuasan petani jagung menggunakan benih bersubsidi, hal ini terlihat dari nilai signifikan 0,008<0,05. Distribusi yang dimaksud dalam penelitian ini adalah bagaimana benih jagung bersubsidi dapat diterima oleh petani. Petani yang berhak mendapatkan benih bersubsidi adalah mereka yang tergabung dalam kelompok tani. Distribusi benih selama ini disalurkan dengan baik kepada petani dan petani juga mudah mendapatkannya ketika benih bersubsidi sudah tersedia. Benih merupakan faktor yang sangat menentukan keberhasilan usahatani jagung, sehingga harus ditangani secara sungguh-sungguh agar dapat tersedia dengan baik dan terjangkau oleh petani. Salah satu kriteria benih bermutu menurut Sadjad (1993) adalah tepat waktu artinya ketika petani memperoleh benih sesuai dengan waktu tanam dan juga iklim yang baik maka dapat memberikan hasil yang baik pada kegiatan pertanian mereka, karena kegiatan pertanian tradisional tidak bisa terlepas dari masalah iklim atau cuaca. Hal ini sesuai dengan penelitian Thaib (2015) dalam penelitiannya bahwa distribusi pupuk urea bersubsidi berpengaruh positif dan signifikan terhadap kepuasan petani di Kecamatan X Kota Kabupaten Tanah Datar.

Berdasarkan hasil output maka rumus persamaan struktural 1 pengaruh produk dan distribusi terhadap kepuasan petani jagung menggunakan benih bersubsidi adalah sebagai berikut: 


\section{$Y_{1}=-0,420$ Produk + 0,548 Distribusi}

Dari persamaan struktural 1 dapat diketahui bahwa nilai produk adalah 0,420 artinya setiap penambahan satu satuan produk maka kepuasan petani akan meningkat sebesar $-0,420$. Selanjutnya nilai distribusi adalah 0,548 artinya setiap penambahan satu satuan distribusi maka kepuasan petani akan meningkat sebesar 0,548.

\section{Pengujian Hipotesis Persamaan Struktural 2}

Berdasarkan Tabel 9 dapat diketahui bahwa koefisien determinasi (R Square) adalah 0,630 atau $63 \%$ artinya pengaruh produk, distribusi dan kepuasan terhadap loyalitas petani jagung menggunakan benih bersubsidi sebesar $63 \%$ sedangkan sisanya $37 \%$ dipengaruhi oleh faktor lain yang tidak diteliti pada penelitian ini.

Tabel 9 Model Summaryb

\begin{tabular}{|c|c|c|c|c|}
\hline Model & $\mathbf{R}$ & R Square & $\begin{array}{l}\text { Adjusted } \\
\text { Square }\end{array}$ & $\begin{array}{ll}R & \begin{array}{l}\text { Std. Error of the } \\
\text { Estimate }\end{array} \\
\end{array}$ \\
\hline 1 & ,794a & ,630 & ,588 & ,51001 \\
\hline
\end{tabular}

Sumber: Hasil Penelitian 2020 (Data Diolah)

\section{Pengujian Secara Serempak (Uji F)}

Hasil analisis data yang dapat dilihat pada Tabel 10 menunjukkan bahwa $\mathrm{F}$ hitung adalah 14,785 dengan tingkat signifikansi $95 \%(\alpha=0,05)$. Oleh karena Fhitung $>$ Ftabel $(14,785>2,975)$ dan nilai signifikansinya $\quad(0,000)<0,05, \quad$ maka produk, distribusi dan kepuasan secara serempak berpengaruh positif dan signifikan terhadap loyalitas petani jagung menggunakan benih bersubsidi.

Tabel 10. ANOVA

\begin{tabular}{|c|c|c|c|c|c|}
\hline Model & Sum of Squares & Df & Mean Square & $\mathbf{F}$ & Sig. \\
\hline 1 Regression & 11,537 & 3 & 3,846 & 14,785 &, $000^{\mathrm{b}}$ \\
\hline Residual & 6,763 & 26 & ,260 & & \\
\hline Total & 18,300 & 29 & & & \\
\hline
\end{tabular}

Sumber: Hasil Penelitian 2020 (Data Diolah)

\section{Hasil Uji Koefisien Jalur Struktural 2}

Hasil output uji analisis jalur kepuasan terhadap loyalitas dapat dilihat persamaan struktural 2 secara parsial yaitu pengaruh produk, distribusi dan pada Tabel 11 berikut: 
Tabel 11. Cofficients ${ }^{\mathrm{a}}$

\begin{tabular}{|c|c|c|c|c|c|}
\hline \multirow[t]{2}{*}{ Model } & \multicolumn{2}{|c|}{$\begin{array}{c}\text { Unstandardized } \\
\text { Coefficients }\end{array}$} & \multirow{2}{*}{$\begin{array}{c}\begin{array}{c}\text { Standardized } \\
\text { Coefficients }\end{array} \\
\text { Beta }\end{array}$} & \multirow[t]{2}{*}{$T$} & \multirow[t]{2}{*}{ Sig. } \\
\hline & $\mathrm{B}$ & Std. Error & & & \\
\hline 1 (Constant) &,- 563 & 1,608 & &,- 350 & ,729 \\
\hline Produk & 182 & ,066 & ,413 & 2,774 & ,010 \\
\hline Distribusi & ,339 & 132 & ,403 & 2,574 & ,016 \\
\hline Kepuasan & ,386 & 178 & 299 & 2,173 & ,039 \\
\hline
\end{tabular}

Sumber: Hasil Penelitian 2020 (Data Diolah)

Berdasarkan Tabel 11 dapat diketahui bahwa:

1. Produk berpengaruh positif dan signifikan terhadap loyalitas petani jagung menggunakan benih bersubsidi, hal ini terlihat dari nilai signifikan $\quad 0,010<0,05$. Menurut Kotler dan Amstrong (2000) loyalitas berasal dari pemenuhan harapan atau harapan konsumen. Loyalitas petani dalam penelitian ini adalah perilaku setia menggunakan benih bersubsidi. Benih subsidi merupakan bantuan dari pemerintah yang dapat mengurangi biaya produksi dan benih merupakan sesuatu yang diperlukan dalam kegiatan usahatani petani. Hal ini sesuai dengan penelitian Ridwan (2019) bahwa kualitas produk berpengaruh langsung terhadap loyalitas pelanggan secara signifikan.

2. Distribusi berpengaruh positif dan signifikan terhadap loyalitas petani jagung menggunakan benih bersubsidi, hal ini terlihat dari nilai signifikan $0,016<0.05$. Loyalitas dapat diartikan sebagai komitmen bertahan. Distribusi menunjukkan hasil positif terhadap loyalitas petani artinya petani tetap memiliki komitmen untuk menggunakan benih jagung bersubsidi. Hal ini sesuai dengan penelitian Thaib (2015) dalam penelitiannya bahwa distribusi berpengaruh positif dan signifikan terhadap loyalitas petani di Kecamatan X Kota Kabupaten Tanah Datar.

3. Kepuasan berpengaruh positif dan signifikan terhadap loyalitas petani jagung menggunakan benih bersubsidi, hal ini terlihat dari nilai signifikan $0,039<0.05$. Kepuasan dapat diartikan terpenuhinya harapan terhadap sesuatu. Dari hasil analisis dapat diketahui bahwa petani jagung puas dengan benih bersubsidi, yang berarti benih jagung bersubsidi memenuhi harapan sehingga petani merasakan manfaat dari benih tersebut yang berakibat kepada loyalitas petani dalam penggunaan benih jagung bersubsidi. Hal ini juga sesuai dengan penelitian Rahmawati et.al (2018) bahwa kepuasan berpengaruh positif terhadap loyalitas petani.

Berdasarkan hasil output tersebut maka rumus persamaan struktural 2 pengaruh produk, distribusi dan 
kepuasan terhadap loyalitas petani jagung menggunakan benih bersubsidi adalah sebagai berikut:

\section{$Y_{2}=0,413$ Produk + 0,403 Distribusi + 0,299 Kepuasan}

Dari persamaan struktural 2 dapat diketahui bahwa nilai produk adalah 0,413 artinya setiap penambahan satu satuan produk maka loyalitas petani akan meningkat sebesar 0,413 dan nilai distribusi adalah 0,403 artinya setiap penambahan satu satuan distribusi maka loyalitas petani akan meningkat sebesar 0,403 selanjutnya nilai kepuasan adalah 0,299 artinya setiap penambahan satu satuan kepuasan petani maka loyalitas petani akan meningkat sebesar 0,299.

\section{SIMPULAN}

Berdasarkan hasil penelitian diperoleh produk dan distribusi produk secara serempak berpengaruh signifikan terhadap kepuasan petani jagung menggunakan benih bersubsidi kemudian secara parsial, produk berpengaruh signifikan terhadap kepuasan petani jagung menggunakan benih bersubsidi, distribusi berpengaruh positif dan signifikan terhadap kepuasan petani jagung menggunakan benih bersubsidi, selanjutnya diketahui bahwa produk, distribusi dan kepuasan secara serempak berpengaruh positif dan signifikan terhadap loyalitas petani jagung menggunakan benih bersubsidi kemudian secara parsial, produk berpengaruh positif dan signifikan terhadap loyalitas petani jagung menggunakan benih bersubsidi, distribusi berpengaruh positif dan signifikan terhadap loyalitas petani jagung menggunakan benih bersubsidi serta kepuasan berpengaruh positif dan signifikan terhadap loyalitas petani jagung menggunakan benih bersubsidi.

\section{DAFTAR PUSTAKA}

Habib, Akbar. 2013. Analisis Faktor-Faktor yang Mempengaruhi Produksi Jagung. Agrium. Vol.18 Nomor 1: 7987

Kotler, Philip dan Amstrong G. 2000. DasarDasar Pemasaran. Edisi Keenem Jilid I. Terjemahan. Jakarta: Intermedia.

Mayrowani, Henny. 2008. Evaluasi Kebijakan Subsidi Benih Jagung Kasus Kabupaten Jeneponto, Sulawesi Selatan. Analisis Kebijakan Pertanian. Vol. 6 Nomor 3: 256-271. Mustikarini, Fibria, Retnaningsih dan Megawati Simanjuntak. 2014. Kepuasan dan Loyalitas Petani Padi Terhadap Pestisida. Jurnal Ilmu Keluarga dan Konsumen. Vol. 7 Nomor 2: 93-102.

Rahmawati, Gresia, Mohd. Harisudin dan Hanifah Ihsaniyati. 2018. Loyalitas Petani Dalam Melakukan Pembelian Benih Padi Produksi PP Kerja Di Solo Raya. SEPA. Vol. 14 Nomor: 2: 135-145.

Ridwan, B.D., J.T. Ibrahim, A. Bakhtiar. 2019. Pengaruh Kualitas Produk Buncis A.S. Terhadap Loyalitas Pelanggan Cv A.S. di Kecamatan Karangploso Kabupaten Malang. JSEP. Vol.15 Nomor 2: 105-113.

Rukmana, Rahmat. 2011. Usahatani Jagung. Yogyakarta: Kanisius.

Sadjad S. 1993. Dari Benih Kepada Benih. Jakarta: Gramedia.

Sangadji, Mamang Etta dan Sopiah. 2013. Perilaku Konsumen Pendekatan 
Praktis disertai: Himpunan Jurnal Penelitian. Yogyakarta: Andi.

Sinulingga, Sukaria. 2013. Metode Penelitian. Edisi 13. Medan: USU Press.

Sugiyono. 2012. Metode Penelitian Bisnis (Pendekatan Kuantitatif, Kualitatif, dan $R \& D)$. Bandung: Alfabeta.

Thaib, Syafriman, Sefnedi dan Yuhelmi. 2015. Pengaruh Kualitas Pelayanan dan Distribusi Terhadap Loyalitas Petani dalam Menggunakan Pupuk Urea Bersubsidi dengan Kepuasan sebagai Variabel Intervening. Jurnal Program Pascasarjana. Vol 7 Nomor 2.

Tjiptono, Fandy. 2008. Strategi Pemasaran. Edisi 3. Yogyakarta: Andi.

Warisno. 2009. Jagung Hibrida. Yogyakarta: Kanisius. 